\title{
The effects and effectiveness of Accountability and Transparency in Government Sectors
}

\author{
OSHO, Augustine $\mathrm{E}^{1}$, AFOLABI, Matthew $\mathrm{B}^{2}$ \\ ${ }^{I}$ Bursary Department, Ekiti State University, P. M. B. 5363, Ado Ekiti, Nigeria \\ ${ }^{2}$ Accountancy Department, Federal Polytechnic, P. M. B. 5351, Ado Ekiti, Nigeria.
}

\begin{abstract}
The study examined and ascertained the extent to which accountability, effectiveness and efficiency mechanism are being promoted and the problems that serve as hindrances to this in Ekiti State. All the data used were both the primary and secondary. Data were primarily gathered through questionnaires administered to the employees of the Nigerian Government Enterprises selected from ministries of Health, Education, Agriculture and Finance sectors at all levels of management. Secondary data were obtained through various magazines of professional associations in Nigeria, journals, newspaper and text books etc and mostly through the internet. Cross tabulation and chi-square were used to analysed the data and the study revealed that the internal control system in the state are very weak, accountability are as well ineffective due to political interference. Base on the findings, effective internal control systems that are free from interference will be needed. This will require political will at both the federal, state and local government areas.
\end{abstract}

Keywords: Accountability, Financial Accountability, Financial Control Systems, Government Activities, Government Sectors, Growth, Transparency

\section{Introduction}

Financial accountability is ultimately about promoting and reporting public and performance. Public financial accountability requires that governments manage finance prudently; that they integrate their financial and non financial reporting, control, budgeting and performance; that they report comprehensively on what they achieved with their expenditure of funds, and that stakeholders behave ethically. Any organization (public or private) that manages and reports on its finance, mitigates the risk of malfeasance, builds good quality and openness into its financial and non-financial analyses, monitors the sustainability of benefits that accrue from its investments, and fulfils its performance reporting and fiduciary obligations to its constituents reflects sound financial accountability. Manifesting financial accountability is therefore much more than building and maintaining accounting and auditing systems. It represents more than just the technical capability of financial managers. Accountability is not complete until it encompasses the wide - ranging activities, attitudes and reporting between stakeholders.

Therefore, while the borrower's fiduciary accountability to the Bank on the use of project funds is important, the country's fiduciary relationship to its citizen to the use of all public resources (including donor fund) has greater significance. This public aspect of accountability is what differentiates the outlook of a commercial bank from that of a development bank.

Accountability is a concept in ethics and government with several meanings. It is often used synonymously with several meanings. It is often used synonymously with such concepts as responsibility, answerability, blame worthiness, liability and other terms associated with the expectation of account giving. As an aspect of governance, it has been central to discussions related to problems in the public sector, non-profit and private (corporate) worlds.

In leadership roles, accountability is the acknowledgement and assumption of responsibility for actions, products and policies including the administration, governance and the implementation within the role or employment position and encompassing the obligations to explain and answerable for the resulting consequences. Accountability in financial control on government enterprises is seen as a major drive to attaining economic development, but the reverse is the case in all government establishments in Nigeria because the managers of government businesses are not loyal, honest and trustworthy in the discharge of their various responsibilities.

Hence, this paper tries to highlight the various causes and solution to the replete nature of accountability in the socialist economy, where the government of Nigeria is a major stakeholder and the sole controller of her businesses.

With the steady growth of public enterprises in Nigeria, government activities have been increasing and more funds are being expended in pursuit of development. Greater autonomy in local government administration and trends at privatization in some sectors, the character, scope and dimensions of public accountability have now been extended over greater horizons with increased public consciousness, the demand for public 
accountability of persons and bodies managing public resources in ministries, agencies, parastatals and every department. There is greater use for ensuring that all employees of the government sectors in Nigeria be held liable, accountable, responsible and answerable to all actions, demands, challenges of the Nigerian citizens.

The public sectors in Nigeria were established to propel socio-economic development and to guide against the control of the economy from foreign denomination and exploitation. This accounts for why a larger proportion of the national budget has been voted for the creation and sustenance of public sectors. In spite of this, the performance of public enterprises has been replete with varying contradictions. Hence the internal control system and management strategies are being applied in operations of public enterprises of the Nigerian economy as integral parts of the structural Adjustment Program (SAP) in 1986. Hence, there is the need for the effective and efficient applications of both internal control mechanisms and management strategies in all government enterprises in Nigeria.

\section{Purpose of the Study}

The purpose of this study was:

1. To examine the effective and efficient application of financial control systems in government sectors in enhancing accountability

2. To examine the significant improvements in accountability due to the application of management strategies in government sectors.

\section{Research Questions}

Within the scope of the study, the following questions were raised:

1. How does effective and efficient application of financial control systems in government sectors enhance accountability on the Nigerian economy?

2. Does improvement in accountability due to the application of management strategies in government sectors promote accountability in Nigeria?

\section{Hypotheses}

In the light of the introduction of this paper and the objectives discussed above, the researchers develop the following hypotheses:

1. Effective and efficient application of financial control systems in government sectors does not enhance accountability on the Nigerian economy.

2. There is no significant improvement in accountability due to the application of management strategies in government sectors in Nigeria.

\section{Literature Review}

A quick look at one of the common dictionaries reveals that the term accountability means having responsibility for or reporting to others on something, usually funds, materials or personnel utilized in an organization (Goetz, 1988). This definition connotes that anyone managing an organization should be responsible and ready to give periodic account of how effective and efficient the systems had performed over a given period of time. The challenge at hand was to devise institutional mechanism that would make governments accountable for the extraction, allocation and use of revenues that did not come from taxation, yet were abundant enough to alleviate socio-economic inequalities of citizens if the monies were well invested.

Dogo (1990) has alleged that the accounting systems of Government-Owned Companies in Nigeria do not seem to guarantee proper and up-to-date financial records thus making auditing difficult, if not impossible.

Solola (2006) defined control as the measurement and correction of performance in order to make sure that the organizational objectives and plans are accomplished. Planning and controlling are closely related, they are like the Siamese twins that cannot be easily separated. He also stressed further that control is the management skill that helps to ensure that actual activities are in conformity with planned activities.

Williams (2011) has documented the positive effect of transparency on alleviating resources causing problems, while the longstanding relationship between resources abundance and reduced economic growth has been confirmed Williams argues that it is lack of transparency rather than abundant resources revenue parse that may explain delayed economic growth.

Accountability in the public sectors of the Nigerian economy has been defined as the process of being liable and answerable to the employment or responsibilities conferred on someone on how effectively the various commitments are being carried out in such a way that the objectives and goals of the public enterprises will be attained either presently or in the future. Accountability is required in all sectors of the Nigeria economy in order to forestall improvement and development of the nation economy, effective and efficient utilization of her resources, economic growth and many more. 
Hence, accountability in the government enterprises of the Nigeria economy can be achieved and sustained through the effective and efficient application of both internal control mechanisms and management strategies.

\section{Concept of Accountability in the Public Sector of Nigeria}

According to research through the internet, Wikipedia (The Free Encyclopedia), "The Economy of Nigeria". The Nigerian Government is faced with enormous tasks and responsibilities as to making effective and efficient use of the nation endowments, coping with the up surging needs and challenges of the citizens, provision of essential services allocation of the scarce resources to benefit and satisfy the unlimited needs of all and sundry in the nation. Every Nigerian citizen, irrespective of his or her status in the community look forward to getting some basic and indispensable social amenities from the government such as good pipe-borne water, good roads and infrastructural facilities, good health delivery services in hospitals and clinics, ultra-modern schools conducive for learning, stable power supply, protection and safety of lives and properties, creation of secured job opportunities and so on. All the aforementioned challenges of the Nigerian citizens have not been adequately and effectively provided in the economy due to ineffective accountability in all the various sectors of the Nigerian economy.

More so, the citizens rights and privileges are being denied, projects and agendas planned and awarded are not being executed either by contractors or government officials handling the execution activities and there had been nothing done to curb the situation, there had been no motivation for efficiency on the part of the government to boost the morale of their employees in the economy, hence, the economy is filled with great level of corruption and a high level of poverty due to high unemployment rates.

\section{Lines of Accountability in the Public Enterprises of Nigeria}

There are many sectors in the public enterprises of the Nigeria economy system, out of which four (4) sectors, health, education, agricultural and finance have been selected. Activities in the various sectors affect almost every individual in one way or the other. Thus, in the program of accounting for the progress of the sectors in an economy, each person has a place in the scheme of responsibilities. Each individual employee is responsible to or for someone else and for specific activity or activities toward goals attainment.

Figure 1 below represents a brief analogy of the Public Sectors in Nigeria.

Figure 1: Line of accountability in the selected sectors of the Nigerian Public Sectors.

Accountable To:

\begin{tabular}{|c|c|c|}
\hline \multicolumn{2}{|c|}{ Public (Nigeria citizens) } & Means and enabling environment \\
\hline \multicolumn{2}{|c|}{$\begin{array}{l}\text { National Assembly } \\
\text { (and its various committee) }\end{array}$} & $\begin{array}{l}\text { Policy formulation and } \\
\text { legislations }\end{array}$ \\
\hline \multicolumn{2}{|l|}{ Presidency } & $\begin{array}{l}\text { Selection, employment of staffs and } \\
\text { input accountability }\end{array}$ \\
\hline \multicolumn{3}{|c|}{$\begin{array}{l}\text { Ministers (and their ministries) } \\
\text { Education, Health, Agriculture and } \\
\text { Finance }\end{array}$} \\
\hline \multicolumn{2}{|c|}{\begin{tabular}{l|l}
\multicolumn{1}{c}{ STATUTORY } & ORGANIZATION \\
Education & $\frac{\text { Health }}{\text { NHIS, NACA }}$ \\
NUC, NCCE,NBTE, & \\
NDEC & Finance \\
Agricultural & FRS, IFRS, GAAP \\
Fadiman, ADP \& & ICPC \\
AISA &
\end{tabular}} & $\begin{array}{l}\text { Supervision, monitoring and } \\
\text { evaluation of process (process } \\
\text { accountability) }\end{array}$ \\
\hline
\end{tabular}

\begin{tabular}{|c|c|c|}
\hline & \\
\hline \multicolumn{3}{|c|}{$\begin{array}{l}\text { INSTITUTIONAL ADMINISTRATION } \\
\text { Education }\end{array}$} \\
\hline $\begin{array}{l}\text { Profession, provosts, } \\
\text { Rectors. Vice- Chancellor }\end{array}$ & Professor Doctors, & Resources utilization and output \\
\hline Principals & Fildindersts etc & \\
\hline $\begin{array}{l}\text { Agriculture } \\
\text { Entrepreneurs, Farmer } \\
\text { Auditors }\end{array}$ & $\frac{\text { Finance }}{\text { Accountant, }}$ & \\
\hline
\end{tabular}

Source: Illustration adapted from Luslsegged, A.H. M (1980) 
From the above illustration, it can be deduced that the line of accountability in government sectors is an upward-sloping system of organization.

The four (4) selected starts from the classroom (education), hospitals and clinics (health), farms (agriculture) and cash offices (finance).

They are accountable for the expected outcome of their teachings, treatment of patients, farming and vouching and other interactions with the students or pupils, parents, people and industries and the public respectively within the framework of their national education, health, farming and finance. The teachers, doctors, farmers and cash officers are directly responsible to the institutional administrators that is, headmasters principals, provosts, rectors and vice-chancellor (education), doctors, nurses and professors (health), farmers and entrepreneur (agriculture) and cashiers, accountants, bursars, and treasurers and budget office (finance) for the utilization of resources and output achieved by their institutions at any point in time.

The institution administrators are accountable directly to the various statutory organs set-up to coordinate their affairs such as; National Education Primary Commission (NPEC), National Commission for Colleges of Education (NCCE), National Board for Technical Education (NBTE), and National Universities Commission (NUC) in the Educational sector; National Health Insurance Scheme (NHIS), National Action Committee on Aids (NACA) in the Health sector; Agricultural Development Program (ADP), Agricultural Inputs Supply Agency (AISA), and FADAMA in the Agricultural Sector; and Financial Reporting Standards (FRS), International Financial Reporting Standards (IFRS), and Generally Acceptable Accounting Standards (GAAP) in the Finance Sector of the Nigeria economy.

These statutory bodies are in turn accountable to the ministers of Education, Health, Agriculture and Finance for selection, employment of staff to the institutions and for instructional program inputs to aids the realization of goals in their various ministries. The ministers of Education, Health, Agriculture and Finance along with the ministries are accountable to the presidency for the supervision, selection, evaluation and prioritization of goals and objectives in the various sectors in the nation to ensure that no aspect runs contrary to the other or against the objectives in the national policy on education, health, agriculture and finance.

The presidencies are in turn, accountable to the National Assembly for the formulation of policies and legislation and also implement those policies in order to suit the goals and objectives of each sector. The National Assembly and its committee members are also accountable to the generality of their electorates for the means in terms of funding and enabling environments conducive for educational, health, agricultural and financial pursuits.

\section{Needs for Effective and Efficient Accountability in the Public Sectors of the Nigerian Economy}

A wide range of gap still exists between government sectors in Nigeria and the corporate (private) world due to the following reasons; management of government businesses in Nigeria are corrupt, inexperienced, nonchalant, selfish and are not willing to exert their physical strength as to improving the pace of government businesses, there are no body of rules made and enforced effectively by the management, employees are so lazy, inexperienced, redundant and even do not go to work on daily basis because nobody would challenge them, records of events in government offices are not properly maintained and kept for safety purposes, government properties are always lying idle and no maintenance activities carried out on them either on daily, weekly, monthly or yearly basis, government treasuries are being looted by people in positions of authorities and no remedial action taken against such offenders due to lawlessness, no internal and external auditors to examine and report on the business performances.

Hence, there is the need to forestall efficiency and effectiveness in accountability in all the various establishments of the Nigerian government. The government of Nigeria should endeavor to concentrate on the following needs:

1. The need to set the pace for a sustainable accounting practices and policies for development.

2. The need to boost the morale of government employees and members of the public through the effective and efficient application of internal control mechanisms.

3. The need to segregate duties among employees of public enterprise in the Nigerian economy in order to bring about efficiency in the responsibility given.

4. The need to avoid wasteful spending and unrecorded transactions in the public enterprises.

5. The need to providing goods and quality social services to members of the public.

6. The need to control the resources of the public enterprises through control mechanism (activities) efficiently and effectively.

7. The need to invest more in the public sectors of the economy of Nigeria in order to generate more revenue to the government coffers.

8. The need to allocate resources effectively and efficiently to all the sectors of the Nigerian economy.

9. The need to supervise, monitor and regulate the public enterprises through the statutory organizations.

10. The need to improve and sustain the growth and development of the overall economy of Nigeria. 
11. There should also be a body of rules and regulations guiding the conducts of all employees in the government enterprises of Nigeria and separate body of government be set up to ensure that these rules and regulations are being enforced and strictly adhered to by the employees at all categories.

\section{Methodology}

The researchers used a descriptive research with the aid of four (4) selected number of sectors (educational, health, agricultural, and financed) and the data were generated from both primary and secondary sources. The population consisted of eighty (80) employees of the Nigeria government sectors gotten through stratified random sampling. Twenty (20) employees from educational sector, twenty (20) from health sector, twenty (20) from agricultural sector and twenty (20) from the finance sectors. A total of eighty (80) copies of questionnaire were self administered and served in twenty (20) copies to each of the four (4) selected sectors of government sectors in the Nigerian economy system. In all the eighty (80) copies administered, only seventyseven (77) respondents returned their copies for further analysis. The data collected from the respondents were analyzed in simple percentages and the use of mean with regard to the hypothesis testing. Simple proportion and chi-square $\left(\mathrm{X}^{2}\right)$ method of analysis were used. The null hypotheses were tested using Chi-square $\left(\mathrm{X}^{2}\right)$ Analysis which was tested at $5 \%$ or 0.05 level of significance.

\section{Results}

The data are presented in tables format vividly explained.

Table 1: Does records of activities properly kept and updated in the public sectors?

Source: Survey, 2014

\begin{tabular}{|l|l|l|l|}
\hline Question & Options & Frequency & Percentage \\
\hline 1 & Yes & 50 & 64.94 \\
\hline & No & 27 & 35.06 \\
\hline & Total & 77 & 100 \\
\hline
\end{tabular}

Table 1 shows that $64.94 \%$ of the staff support that records and activities are properly kept and updated in the public enterprises, while $35.06 \%$ did not support the opinion.

Table 2: Do public enterprises operate accountability system in your organization?

\begin{tabular}{|l|l|l|l|}
\hline Question & Options & Frequency & Percentage \\
\hline 2 & Yes & 57 & 74.03 \\
\hline & No & 18 & 23.37 \\
\hline & Undecided & 2 & 2.60 \\
\hline & Total & 77 & 100 \\
\hline
\end{tabular}

Source: Survey, 2014

Table 2 shows that $74.03 \%$ of the respondents agreed that public enterprises operate accountability in their organization, $23.37 \%$ rejected the opinion while $2.60 \%$ of the respondents were undecided.

Table 3: Does employee in public sectors really shown commitment to accountability.

\begin{tabular}{|l|l|l|l|}
\hline Question & Options & Frequency & Percentage \\
\hline 3 & Yes & 60 & 77.92 \\
\hline & No & 12 & 15.58 \\
\hline & Undecided & 5 & 6.50 \\
\hline & Total & 77 & 100 \\
\hline
\end{tabular}

Source: Survey, 2014

Table 3 shows that $77.92 \%$ agreed that employee in public enterprises really show commitment to accountability, $15.88 \%$ were not in support, while $6.50 \%$ of the employees were undecided.

Table 4: Does financial report of government sectors reliable for accountability purpose?

\begin{tabular}{|l|l|l|l|}
\hline Question & Options & Frequency & Percentage \\
\hline 4 & Yes & 57 & 74.03 \\
\hline & No & 19 & 24.07 \\
\hline & Undecided & 1 & 1.30 \\
\hline & Total & 77 & 100 \\
\hline
\end{tabular}

Source: Survey, 2014 
Table 4 shows that $74.03 \%$ of the respondents supported that the financial report of government sectors are reliable for accountability purpose, $24.67 \%$ says the report are poor, while $1.30 \%$ of the respondents are undecided with the opinion.

Table 5: Does remedial action provided for the correction of accuracy of mismanagement of public sectors?

Source: Survey, 2014

\begin{tabular}{|l|l|l|l|}
\hline Question & Option & Frequency & Percentage \\
\hline 5 & Yes & 60 & 77.92 \\
\hline & No & 12 & 15.58 \\
\hline & Undecided & 5 & 6.50 \\
\hline & Total & 77 & 100 \\
\hline
\end{tabular}

Table 5 shows that $77.92 \%$ support that remedial action was not provided for the correction of accuracy of mismanagement of public sectors, $15.58 \%$ did not support while $6.50 \%$ of the employees had no contribution with the opinion.

Table 6: Do you agree that financial control mechanisms are adequately provided and effectively managed in government sectors in Nigeria?

Source: Survey, 2014

\begin{tabular}{|c|c|c|c|}
\hline Question & Options & Frequency & Percentage \\
\hline \multirow[t]{4}{*}{6} & Agreed & 57 & 74.03 \\
\hline & Disagreed & 18 & 23.07 \\
\hline & Undecided & 2 & 2.60 \\
\hline & Total & 77 & 100 \\
\hline
\end{tabular}

Table 6 show that $74.03 \%$ of the respondents agreed that financial control mechanisms are adequately established and effectively managed $23.37 \%$ were against it, while $2.60 \%$ of the respondents were undecided.

Table 7: Do you agree that strategies are being mapped out and applied to sustain accountability in Nigeria public sectors?

Source: Survey, 2014

\begin{tabular}{|l|l|l|l|}
\hline Question & Options & Frequency & Percentage \\
\hline 7 & Agreed & 50 & 64.94 \\
\hline & Disagreed & 27 & 35.06 \\
\hline & Undecided & - & - \\
\hline & Total & 77 & 100 \\
\hline
\end{tabular}

Table 7 shows that $64.94 \%$ of the staffs agreed that strategies are being mapped out and applied to sustain accountability in public sectors while $35.06 \%$ did not agree with the opinion and none was in the position of undecided.

Table 8: Do you agree that corrupt officials of the public sectors take advantages of any loopholes in the control of financial system to perpetrate their fraudulent manipulative and other social vices in the public sectors.

Source: Survey, 2014

\begin{tabular}{|l|l|l|l|}
\hline Question & Options & Frequency & Percentage \\
\hline 8 & Agreed & 60 & 77.92 \\
\hline & Disagreed & 12 & 15.58 \\
\hline & Undecided & 5 & 6.50 \\
\hline & Total & 77 & 100 \\
\hline
\end{tabular}

Table 8: shows that $77.92 \%$ support that corrupt officials of public enterprises take advantages of loopholes in the financial control system to perpetrate their fraudulent manipulative and other social vices in the public sectors, $15.58 \%$ were not in support, while $6.50 \%$ of the employees were undecided with the opinion.

Table 9: Do you agree that employees of public sectors are accountable?

Source: Survey, 2014

\begin{tabular}{|l|l|l|l|}
\hline Question & Options & Frequency & Percentages \\
\hline 9 & Agreed & 50 & 64.94 \\
\hline & Disagreed & 27 & 35.06 \\
\hline & Undecided & - & - \\
\hline & Total & 77 & 100 \\
\hline
\end{tabular}


Table 9 shows that $64.94 \%$ of the staff agreed that employee of government sectors are accountable while $35.06 \%$ were not agreed with the opinion.

\section{Hypotheses Testing}

A lot of analysis has been made with the aid of percentage formulae. The researchers, therefore wished to adopt the chi-square $\left(\mathrm{X}^{2}\right)$ method in testing the hypotheses. These are tested based on the objectives and assumptions derived from the research hypothesis.

\section{Hypothesis 1}

Efficient and effective application of financial control systems in public sectors does not enhance accountability on the Nigerian economy.

Ho: $X^{2}=\frac{E(O-E)^{2}}{E}$

Where $\mathrm{X}^{2}=$ Chi-square

$\mathrm{E}=$ Summation

$\mathrm{O}=$ Observed frequency

$\mathrm{Df}=\mathrm{k}-1$

$\mathrm{E}=$ Expected frequency

Where, $\mathrm{Df}=$ The degree of freedom

$\mathrm{K}=$ Number of observed frequency

Test the hypothesis of relationship at $5 \%$ or 0.05 levels of significances using the various positions and hierarchies of responsibilities in government sectors which form the basis of accountability.

$$
\begin{aligned}
\mathrm{X}^{2}= & 16.703 \\
\text { Df } & =\mathrm{k}-1 \\
& =3-1 \\
& =2
\end{aligned}
$$

\begin{tabular}{|l|l|l|c|l|}
\hline Level & O & E & O-E & $(\mathbf{O - E})^{2} / \mathbf{E}$ \\
\hline Top & 10 & 25.67 & -15.67 & 9.57 \\
\hline Middle & 28 & 25.67 & 2.23 & 0.211 \\
\hline Lower & 39 & 25.67 & 13.34 & 6.922 \\
\hline Total & 77 & 77 & 0 & 16.703 \\
\hline
\end{tabular}

Since, $\mathrm{Df}=0.05$ level of significance

Therefore, $\mathrm{X}^{2} 0.95=16.703$

$$
=5.99
$$

From the results above, the calculated value for $\mathrm{X}^{2}$ is 16.703 at 0.05 level of significance while the degree of freedom is 5.99. Since the calculated value of $X^{2}=16.703$ is greater than the table value of $X^{2}=$ 5.99 , the null hypothesis is rejected while the alternative hypothesis is accepted.

\section{Hypothesis 2}

There is no significance improvement in accountability due to the application of management strategies in government sectors in Nigeria.

$$
\begin{aligned}
& \text { Ho: } \mathrm{X}^{2}=\frac{\mathrm{E}(\mathrm{O}-\mathrm{E})}{\mathrm{E}} \\
& \begin{aligned}
\text { Where } \mathrm{X}^{2} & =\text { Chi-square } \\
\mathrm{E} & =\text { Summation } \\
\mathrm{O} & =\text { Observed frequency } \\
\mathrm{E} & =\text { Expected frequency } \\
\text { Df }=\mathrm{k}-1 & \\
\text { Where, Df } & =\text { The degree of freedom } \\
\mathrm{K} & =\text { Number of observed frequency }
\end{aligned}
\end{aligned}
$$
qualification

Test the hypothesis of relationship at $5 \%$ or 0.05 level of significance using the employees educational

\begin{tabular}{|l|c|l|l|l|}
\hline Level & O & E & O-E & $(\mathbf{O}-\mathbf{E})^{2} / \mathbf{E}$ \\
\hline SSCE/NCE/OND & 39 & 19.25 & 19.75 & 20.263 \\
\hline HND/BSC/BA & 28 & 19.25 & 8.75 & 3.977 \\
\hline MBA/MSC/ICAN & 9 & 19.25 & -10.25 & 5.458 \\
\hline PH.D & 1 & 19.25 & -18.25 & 17.302 \\
\hline Total & 77 & 77 & & $\mathrm{X}^{2}=47$ \\
\hline
\end{tabular}

$\mathrm{X}^{2}=47$ 


$$
\begin{aligned}
\text { Df } & =\mathrm{k}-1 \\
& =4-1 \\
& =3
\end{aligned}
$$

Since, $\mathrm{Df}=0.05$ level of significance

Therefore, $\mathrm{X}^{2} 0.95=47$

$$
=16.855=16.86
$$

Since the calculated value of $X^{2}=47$ is greater than the table value of $X^{2}=16.86$, the null hypothesis is rejected while alternative hypothesis is accepted.

\section{Discussion}

The findings revealed that the effective and efficient application of financial control measures and management strategies to accountability in government sectors will compel each employee to be more serious, focused and loyal in the discharge of his / her responsibilities since the personal data of each employee will be taken by the government and he/she will be solely held liable for every actions in the sectors.

Also in section B, public opinion on the performances of government employees are gathered and the government itself through its agencies and parastatals. Hypothesis formulated were tested and results interpreted to measure the overall performance of government enterprises in Nigeria. The overall geared towards forestalling and sustaining accountability in all the sectors of the Nigeria Economy.

\section{Conclusion}

Financial control and accountability in government sectors in Nigeria is a very important key to driving the economy to its greater heights. Hence, all the sections in the government enterprises in the Nigerian economy must ensure that measures are put in place to hold each employee liable for every actions and consequences in the various sectors. A well defined line of accountability is drawn up to clearly state the positions, duties and responsibilities of each employee in the various sectors of government enterprises and the passage of information, transfer of obligations from one level of staff to the other in an upward sloping format.

In the arrays of public sectors in Nigeria; Educational, oil and gas, industrial, infrastructural, power and energy, transportation, maritime, finance, agricultural, health and so on. They need to supply the concept of financial control systems and management strategies highlighted in the paper, not only for accountability purposes but also to boost productivity, provide essential services for the citizenry and guidance to implementing government agenda and for the restructuring of the government sectors in Nigeria.

Findings revealed that effective and efficient application of financial control systems and management strategies to accountability in public sectors will enable remedial actions to be taken as variance sets in. There should be clearly defined policies and procedures formulated objectives as well as showing in-depth, the position, authority and responsibility of each employee and the activity for which they are responsible, information should be made available and communicated for the purposes of discharging each person responsibility. Standard procedures of reporting should be established where accountability is effectively and efficiently desired as a tool towards attaining organizational goal.

Accountability is not an end in itself; it is a means to an end. By evaluating and indicating how efficiently a given resource allocation or service strategy had produced the desired outcome and by diagnosing the reason for failure when failure occurs, product or outcome accountability technique combined with proper supervision would help the government sectors to improve. Accountability is a means by which valid and appropriate goals and objectives are determined, the progress made towards their achievement is measured; factors and conditions facilitating or retarding outcome are assessed and of programs planned. The main aim of accountability is the improvement of the services delivered for the benefit of the public individuals in general and this can be achieved through the efficient and effective application of both financial control systems and management strategies in government sectors.

\section{Recommendations}

The overwhelming significance on the efficient and effective of financial control and accountability on government enterprises in Nigeria is based on the findings and observation from the study.

In order to sustain accountability in government sectors, government at all levels; Federal, State and Local levels should be guided by the following controls and strategies.

I. Enable remedial actions to be taken on employees as variance emerge from the discharge of their responsibilities.

II. Motivate employees by making them participate in the planning procedures, setting of standards controlling processes, and also organize sensitization programs for them.

III. Improve the allocation of scarce resources through the implication of internal control mechanism and management strategies in public sectors. 
IV. Government should employ more professionally qualified personnel to carry out its control and planning processes.

V. Provide incentives to staff in order to encourage good services delivery and implement all plans and budgeting.

VI. Inculcate accounting principles for accountability purposes in government sectors.

VII. Improve the release of funds to all sectors in the enterprises of the government in Nigeria.

VIII. Set standards and procedures to control the behaviors of each employee (moral or ethical accountability)

IX. Set up regulatory organs of government both internally and externally, for proper monitoring and supervision of all the government sectors in Nigeria.

$\mathrm{X}$. Ensure strict compliance is given to all rules and regulations, procedures and plans in order to attain the goals of government sectors in Nigeria.

XI. Engage the work of an internal auditor in all the sectors of government sectors in Nigeria.

\section{References}

[1]. Dogo, 1. (1990): "Management of Cost and prices in Nigerian Public Enterprises" Nigerian Management Review Vol. 5 Nos. 1 $\& 2$

[2]. Goetz, P. W (Ed) (1988): The New Encyclopedia Britannica, Chicago, Encyclopedia Britannica Inc., vol.1.

[3]. Luslsegged, A.H. M (1980) the Supervisor concerned with Accountability in Education, UNDP/UNESCO project, University of Ibadan, p.6

[4]. Solola H. E (2006): The measurement and correction of performance in public sector

[5]. Williams, A (2011): Shining a light on the Resource Curse: An Empirical Analysis of the Relation between Natural Resources, Transparency, and Economic Growth.

[6]. Wikipedia, The free Encyclopedia. The Economy of Nigeria. htt://en.wikipedia.org/wiki/Economyofnigeria

\section{Appendix}

\section{Questionnaire}

[1]. Do record of activities properly kept and updated in the public sectors? Yes $\{\quad\} \quad$ (b) No $\{\quad\}$ (c) Undecided $\{\quad\}$

[2]. Do public enterprises operate accountability system in your organization?(a)Yes $\left\{\begin{array}{llll}\text { (b) No }\{\text { (c) Undecided }\{\}\end{array}\right.$

[3]. Does employee in public sector really show interest and commitment to accountability?. (a)Yes \{\} (b) No $\}\}$ Undecided \{\}

[4]. Does financial report of government sectors reliable for accountability purpose? (a)Yes $\left\{\begin{array}{llll}\text { (b) No }\{\quad \text { (c) Undecided }\{\quad\}\end{array}\right.$

[5]. 5. Do you agree that financial control mechanism are adequately provided and effectively managed in government sectors in Nigeria? Agreed \{\}$\quad$ (b) Disagreed \{\}$\quad$ (c) Undecided \{\}

[6]. Do you agree that strategies are being mapped out and applied to sustained accountability in Nigeria public enterprises? Agreed \{ \} (b) Disagreed $\{\quad\} \quad$ (c) Undecided $\{\quad\}$

[7]. 7. Do you agree that corrupt officials of public enterprisers take advantage of any loophole in the control financial system to penetrate their fraudulent, manipulative and other social vices in the Nigeria economy? Agreed $\left\{\begin{array}{llll}\text { (b) Disagreed }\{\}\end{array}\right.$ (c)Undecided \{\}

[8]. 8. Do you agree that funds are promptly and adequately released to all the public sectors in Nigeria?’Agreed $\{\quad$ (b) Disagreed $\{$ \} (c) Undecided \{\}

[9]. 9. Do you agree that employee of public sectors are accountable? (a) Agreed $\{\quad\}$ (b) Disagreed \{\} (c) Undecided \{\} 